\title{
Hjernetomt om hjerneblødning
}

Medisinske metaforer brukes ofte i dagligtalen og i mediebildet, men ikke alle uttrykk er like heldige.

Tom Nordlie tok over som trener for nedrykkstruede Sandnes Ulf og ledet første kamp 26.7. 2014 mot Strømsgodset. Sandnes Ulf tapte 1-3. Etter kampen uttalte Nordlie til Nettavisen at «tre hjerneblødninger senket oss» (1).

\section{Å gjøre en hjerneblødning}

Nordlie utdypet videre i innlegget: «I første omgang gjør vi en hjerneblødning, og i den andre gjør vi to til. Da blir du straffet mot gode lag som Strømsgodset. Enkelt og greit så er de mer effektive og giftige enn oss når de får muligheten til å score mål» (1).

Det er interessant at Nordlie bruker hjerneblødning som metafor for dårlig forsvarsspill, men måten han fremstiller det på viser liten innsikt i hjerneblødningsbegrepet. Mener han subaraknoidal, intracerebral, subdural eller epidural blødning? Sannsynligvis førstnevnte. Fotballspillerne var dog oppegående både før, under og etter «hjerneblødningen», noe som sjelden er tilfelle etter subaraknoidalblødning. TIA (transitorisk iskemisk anfall), eller det mer folkelige drypp hadde kanskje vært en mer passende metafor, om man er helt nødt til å bruke en eller annen cerebrovaskulær metafor i en slik sammenheng.

\section{Verkebyll}

Medisinske metaforer brukes ofte i dagligtalen og i mediebildet. Eksempler er kreftsvulst, verkebyll, hodepine, akilleshæl, hjernedød, koma, blodfattig, pulsåre, blodpropp, forløsning og parasitt. Listen kan gjøres mye lengre.

Selv om dårlig forsvarsspill må være grusomt å se på for en fotballtrener, hadde det etter min mening vært fornuftig å ordlegge seg på en annen måte. For pasienter med sekvele etter hjerneblødning er hverdagen en helt annen enn noen sekunders ubesluttsomhet på en fotballbane. Nordlie, som tidligere blant annet har profilert seg som salgsdirektør i et firma som selger hjertestartere (2), burde ha visst bedre. Det kan være fornuftig å bruke medisinske meta-
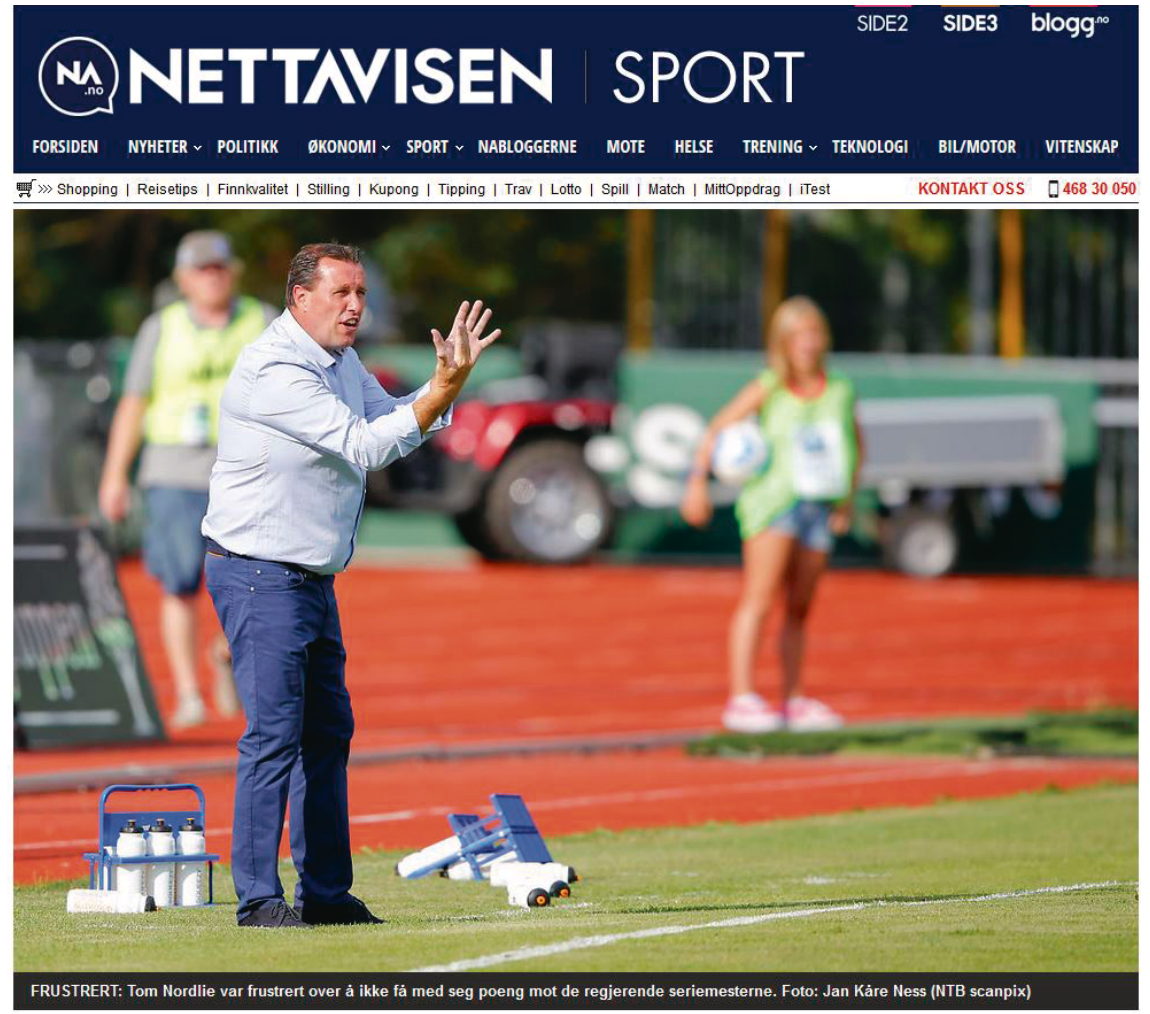

\section{- Tre hjerneblødninger senket oss}

Faksimile fra Nettavisen 26.7. 2014 (1)

forer, men dette eksemplet er, etter min mening, helt bak mål.

\section{Kashif Waqar Faiz}

kashif.faiz@medisin.uio.no

Kashif Waqar Faiz (f. 1978) er konstituert avdelingssjef ved Avdeling for akuttmedisin, Medisinsk divisjon, Akershus universitetssykehus.

\footnotetext{
Litteratur

1. Tre hjerneblødninger senket oss. Nettavisen 26.7.2014.www.nettavisen.no/sport/fotball/ --tre-hjernebldninger-senket-oss/8469000.html (31.7.2014).

2. Ny jobb for Tom Nordlie. Aftenposten 3.2.2011. www.aftenposten.no/100Sport/fotball/forsesong/ Ny-jobb-for-Nordlie-172698_1.snd (31.7.2014).
}

Mottatt 31.7. 2014, første revisjon innsendt 20.8. 2014, godkjent 8.9. 2014. Redaktør: Marit Skaar Fjellhaug. 